\title{
"Righting", Restructuring, and Rejuvenating The Postcolonial African State: The Case For The Establishment of an AU Special Commission On National Minorities
}

Obiora Chinedu Okafor

Osgoode Hall Law School of York University, ookafor@osgoode.yorku.ca

\section{Source Publication:}

African Yearbook of International Law. Volume 13, Issue 1 (2005), p. 43-64.

Follow this and additional works at: https://digitalcommons.osgoode.yorku.ca/scholarly_works

\section{cc) (i) $\ominus$}

This work is licensed under a Creative Commons Attribution-Noncommercial-No Derivative Works 4.0 License.

\section{Recommended Citation}

Okafor, Obiora Chinedu. "'"Righting", Restructuring, and Rejuvenating The Postcolonial African State: The Case For The Establishment of an AU Special Commission On National Minorities." African Yearbook of International Law 13.1 (2005): 43-64.

This Article is brought to you for free and open access by the Faculty Scholarship at Osgoode Digital Commons. It has been accepted for inclusion in Articles \& Book Chapters by an authorized administrator of Osgoode Digital Commons. 


\title{
“RIGHTING," RESTRUCTURING, AND REJUVENATING THE POSTCOLONIAL AFRICAN STATE: THE CASE FOR THE ESTABLISHMENT OF AN AU SPECIAL COMMISSION ON NATIONAL MINORITIES
}

\author{
Obiora Chinedu Okafor ${ }^{*}$
}

\section{Introduction}

The special theme of this volume of the Yearbook, i.e. "Reflections on Some Forms of Statehood in Africa," invites contributor and reader alike to grapple with an abstract concept that has nevertheless proved to be highly consequential to the lived experience of virtually every African - at least since the mid-nineteenth century. Despite the increasingly extensive literature on the subject, ${ }^{1}$ both within and

* Associate Professor, Osgoode Hall Law School of York University, Toronto, Canada. Ph.D, LL.M (University of British Columbia, Vancouver, Canada); LL.M, LL.B (Hons) (University of Nigeria, Enugu Campus). I should like to thank Dr. Tiyanjana Maluwa, the H. Laddie and Linda P. Montague Professor of Law at the Dickinson School of Law, The Pennsylvania State University, Carlisle, Pennsylvania, USA, for inviting this article; and Chikeziri Igwe for his able research assistance.

1 For a few samples, see Mutua (M.), "Why Redraw the Map of Africa: A Moral and Legal Inquiry" (1995) 16 Michigan Journal of International Law 1113; Wallace-Bruce (N.L.), "Africa and International Law - The Emergence to Statehood" (1985) 23 The Journal of Modern African Studies 575; Zolberg (A.R.), "The Specter of Anarchy: African States Verging on Dissolution" (1992) Dissent 303; Beissinger (M.R) and Young (C.), Beyond State Crisis? Postcolonial Africa and Post-Soviet Eurasia in Comparative Perspective (Washington D.C.: The Johns Hopkins University Press, 2002); Murithi (T.), The African union: Pan-Africanism, Peacebuilding and Development (Aldershot: Ashgate, 2005); and Okafor (O.C.), Re-Defining Legitimate Statehood: International Law and State Fragmentation in Africa (The Hague: Martinus Nijhoff, 2000) (hereinafter "Re-Defining"). 
without the legal academe, the topic is so complex, so controversial, so socially relevant, and so widely misunderstood still, that it does deserve further attention in a Yearbook such as this.

The objective of this article is to contribute in a modest way to the process of producing ever more accurate scholarly and policy understanding with regard to this very complicated socio-legal subject. To this end, the article will develop systematically an analytical case for the establishment of an African Union (AU) Special Commission on National Minorities as a way of beginning a viable process of resolving the national minority problem that underlies the structural legitimacy crisis that has afflicted the postcolonial African state from its very beginning as the successor of the colonial African state. In order to make this case, the article has been divided into five sections, including this introduction. In section 2 , the nature of the national minority problem within the postcolonial African state is explicated. In section 3, the normative imperative of rejuvenating the postcolonial African state through its righting ${ }^{2}$ and restructuring is discussed. Thereafter, section 4 develops - in as full a fashion as space allows - a case for the establishment of a particular kind of inter-African institution, i.e. the Special Commission on National Minorities, to facilitate and bolster the normatively imperative process of righting, restructuring - and therefore rejuvenating, the postcolonial African state. Section 5 concludes the article.

At the outset, it must be noted that the argument that is made in this article in favour of the establishment of a new institution that can make an important contribution to the peaceable management of the state legitimacy crisis that afflicts the postcolonial African state and which has almost completely crippled a few such states, is not in any way a suggestion that the postcolonial African state should be reconstituted in its present form with the help of this proposed institution. If anything, it is an argument that this state should be

2 I have borrowed the term "righting" from the work of Karen Knop. See Knop (K.), "The 'Righting' of Recognition: Recognition of States in Eastern Europe and the Soviet Union" in Le Bouthillier (Y.), McRae (D.M.) and Pharand (D.) (eds.), Selected Papers in International Law: The Contribution of the Canadian Council on International Law (The Hague: Kluwer, 1999) at 261. 
reconfigured peaceably through a process that is framed by international human rights law and ordered in part by a process that is created by this institution, lest that state continue to be reconfigured in as conflict-ridden and violent a way as it so far has, at least for the most part. ${ }^{3}$ Surely, even when ideally operated - which has not been the case - the current structure of the postcolonial African state cannot be the only viable way of configuring statehood in Africa?

Another caveat that must be entered at the outset is that the author's cautious faith in the value-added of the institution the establishment of which is proposed in this article does not imply the promotion of the uncritical reliance on international institutions and procedures as panaceas. The pitfalls of such an approach are well documented. ${ }^{4}$ What the author's cautious confidence in the capacity of such an institution to make a difference does imply, however, is a limited faith in such institutions as resources in the hands of the human agents (such as local activists, the leadership of minority groups, and even diplomats). Viewed as resources, our expectations regarding the possible achievements of these institutions will become more limited, and therefore more realistic and accurate.

Needless to say, this article - especially its first two substantive sections - draws from some of my previous work in this general area. However, the article seeks to add value to the debate on statehood in Africa not just by deploying to the current terrain of enquiry important insights from that previous work, but also by offering a fresh perspective on some of the arguments in support of my earlier proposals for the establishment, within the structures of the defunct Organization of African Unity (OAU), ${ }^{5}$ of a Special Commission on

3 See Mutua (M.), "Putting Humpty Dumpty Back Together Again: The Dilemmas of the Post-Colonial African State" (1995) 21 Brooklyn Journal of International Law 505, at 536.

4 For example, see Kennedy (D.), "A New World Order: Yesterday, Today and Tomorrow" (1994) 4 Transnational Law and Contemporary Problems 329, at 339-357; and Kennedy (D.), "The Move to Institutions" (1987) 8 Cardozo Law Review 841.

5 Pursuant to the adoption of the Constitutive Act of the African Union, on-line: (http://www.africa-union.org/root/au/AboutAu/Constitutive_Act_en.htm) (visited 24 May 2006), on 1 July 2000, the OAU was formally dissolved in 2002 and replaced by the AU. See also Decision of the Assembly of Heads of State of the African Union, OAU Doc. AHG/AU/AEC/Dec. (I) (9-10 July 2002). On this 
National Minorities. ${ }^{6}$ The other important way in which value is added to the relevant body of literature by this article is through its further development, within the more contemporary context of the new African Union, ${ }^{7}$ of my previously offered argument for the creation of this institution.

\section{The National Minorities Problem within the Postcolonial African State}

It is hardly controversial to argue that the relationship between almost all postcolonial African states and the national minorities who form the bulk of the sub-state groups that constitute nearly every one of these states has, to say the least, been highly problematic. Less well recognized in the literature is the fact that this problematic situation has been, and will for the foreseeable future remain, the central problem of post-colonial African statecraft. $^{8}$ Nevertheless, most observers of African politics would agree that as the Constitutive Act of the African Union has itself declared "the scourge of conflicts in Africa constitutes a major impediment to the socio-economic development of the continent." "Yet, since nearly every single one of these conflicts in Africa has quite remarkably been internal, or better still intra-state in nature, ${ }^{10}$ and since virtually all of these intra-state conflicts have involved tensions over the practical enjoyment (or the

and similar issues, see Udombana (N.J.), "The Unfinished Business: Conflicts, the African Union and the New Partnership for Africa's Development" (2003) 35 George Washington University International Law Review 55, at 55-56 (hereinafter "Unfinished Business")..

6 See Okafor (O.C.), "Re-Defining", supra note 1 at 183-192. See also Okafor (O.C.), "The African System on Human and Peoples' Rights, QuasiConstructivism, and the Possibility of Peacebuilding within African States" (2004) 8 International Journal of Human Rights 413 at 443; and Okafor (O.C.), "Convention Refugeehood, Early Warning Signs, and the Structural Crisis of Legitimate Statehood in Contemporary Nigeria" (2003) 9 Buffalo Human Rights Law Review 1 at 6.

7 See the Constitutive Act of the African Union, supra note 4.

8 See Okafor (O.C.), “After Martyrdom: International Law, Sub-State Groups, and the Construction of Legitimate Statehood in Africa" (2000) 41 Harvard International Law Journal 503 (hereinafter "Martyrdom").

9 See the Preamble of the Constitutive Act of the African Union, supra note 4.

10 See Udombana (N.J.), "Unfinished Business", supra note 4 at 59. 
lack thereof) of group rights/interests within the relevant states, it appears that inter-group conflicts (mostly of the majority/minority type) have at the very least been one major impediment to the effectiveness of the postcolonial African state. What is more, based on my own careful observation of the dynamics of the politics of state formation in Africa, I am of the view that the seemingly incessant inter-group tensions that underlie almost all of the intra-state conflicts that occur within the postcolonial African state is - at least in terms of its scale, prevalence and consequences - the key African statebuilding problem of our time. This point is easily illustrated.

Throughout its postcolonial history, and even before, the postcolonial African state has been typically beset by inter-group tensions, crises, and violence. As Makau Mutua has brilliantly argued, viewed from the perspective of the desirability of generally cohesive or widely accepted states with a reasonable chance of attaining effectiveness, the postcolonial African state never really had a chance in the first place. ${ }^{11} \mathrm{~A}$ brief review of a sample of such states will serve to illustrate the nature of the structural illegitimacy that has seriously threatened the viability of the postcolonial African state. In the Democratic Republic of the Congo (i.e. the former Zaire), "multiple secessions and inter-ethnic conflict followed [its] independence" from Belgium in $1960 .^{12}$ Chief among these tensions and conflicts was the secessionist rebellion of the people of the Katanga (later Shaba) area. ${ }^{13}$ That some, if not all, of these tensions and conflicts have survived to this day, mostly via their exacerbation, manipulation and reification by certain political leaders is in part ably illustrated by the minority rights and secession claims made before the African Commission on Human and Peoples' Rights in the now famous and relatively recent Katanga Case. ${ }^{14}$ In Rwanda, longstanding tensions, conflicts, and violence between the Hutu numerical majority and Tutsi minority eventually escalated into one of the most well-known

11 See Mutua (M.), supra note 2.

12 See McNulty (M.), "The Collapse of Zaire: Implosion, Revolution or External Sabotage?" (1999) 37 The Journal of Modern African Studies 53, at 54.

13 Ibid. at 62.

14 See Katangese Peoples ' Congress v. Zaire (1996) 3 International Human Rights Reports 136. 
genocidal episodes in human history. ${ }^{15}$ While, Rwandan society has to some extent begun the long process of recovery and reconciliation, there is as yet no reliable evidence that the underlying tensions that led to the genocide have fully died down. The conflict in Burundi, which has lasted some ten years and killed well over two hundred thousand people and has, in Udombana's fitting words, left that country "paralyzed", is similarly based on structural tensions between a fearful but powerful Tutsi minority and a less powerful but far more populous Hutu majority. ${ }^{16}$ While this conflict is now formally over, there is little evidence to suggest that the inter-group resentment and tensions that spawned it are no longer prevalent, even if in a slightly milder form. In Nigeria, the recent upsurge in violence in the oil-rich Niger Delta region, instigated for the most part by the militant wings of the various minority rights movements that populate that area, only underlines the intensity of much inter-group tensions in Africa's vastly most populous country. ${ }^{17}$ The Biafran war that was fought mostly in the Igbo-dominated Eastern region of Nigeria in the late 1960 s is perhaps the most negative consequence so far of this sort of intense tension. ${ }^{18}$ Just as the decades old inter-group conflict in the Sudan between the somewhat "Arabized" North and the "non-Arabized" South waned and ended in a peace deal, a similarly destructive inter-group conflict broke out in the Darfur region of that same country. ${ }^{19}$ While a peace deal was signed in mid-2006 by some of the sides to the Darfur conflict (the central regime in Khartoum included), there is little room for so optimistic an assessment that would declare most inter-group tensions "dead and buried" in that vast

15 See Hintjens (H.M.), "Explaining the 1994 Genocide in Rwanda" (1999) 37 The Journal of Modern African Studies 241.

16 See Udombana (N.J.), "Unfinished Business" supra note 4 at 61-62.

17 See Human Rights Watch, They Do Not Own This Place: Government Discrimination Against 'Non-Indigenes' in Nigeria (New York, Human Rights Watch, 2006) at 7-8; "Militants Kill 4 Policemen in Port Harcourt" Thisday, 15 May 2006, on-line: (http://www.thisdayonline.com/nview.php?id+48166\&printer_friendly=1) (visited 15 May 2006).

18 See Forsyth (F.), The Dogs of War (New York: Viking Press, 1974).

19 See Human Rights Watch, Darfur: Humanitarian Aid under Siege (New York: Human Rights Watch, 2006) at 6. 
but deeply troubled country. ${ }^{20}$ More generally, Joel Ngugi was correct when he noted that Africa's "indigenous peoples" (who are almost always also minority groups) have been subjected to very serious ill-treatment that has too often generated high tension, conflict and violence. $^{21}$ While the foregoing is by no means a comprehensive rendering of the inter-group tensions and conflicts that afflict the post-colonial African state, it suffices to illustrate the centrality of such tensions and conflicts to statecraft in Africa, as well as its status as the key challenge of contemporary African state-building praxis. ${ }^{22}$

It is important, however, to note, as I have shown elsewhere, that contrary to the conventional wisdom, this tendency to be characterized by tensions, crisis and violence - one which has marked and marred the history of the postcolonial African state - is not uniquely African and has less to do with the much touted incapacity of Africans to govern themselves or to build large and effective centralized states than with the daunting challenges of state-building posed by the particular character of the state-formation processes that produced the postcolonial African state as we currently know it. ${ }^{23}$

Thus, the serious national minority problems that face the postcolonial African state are mostly structural in nature. ${ }^{24}$ This does not of course discount the role of human agency in the generation of these problems. The structural nature of this problem stems for the most part from the structural illegitimacy of almost all such states in Africa. ${ }^{25}$ In the main, such illegitimacy has derived from the postcolonial African state's lack of sufficient affinity with its constituent sub-state groups, and its origins as a generally unalloyed external imposition rather than as a largely organic entity created

20 The Guardian (Nigeria), 17 May 2006.

21 See Ngugi (J.), "The Decolonization-Modernization Interface and the Plight of Indigenous Peoples in Post-Colonial Development Discourse in Africa" (2002) 20 Wisconsin International Law Journal 297.

For other examples, see Jinadu (L.A.), "Explaining and Managing Ethnic Conflict in Africa: Towards a Cultural Theory of Democracy," Lecture Delivered at the Uppsala University Forum for International and Area Studies, 5 February 2004 (on file with the author).

23 See Okafor (O.C.), "Martyrdom," supra note 7 at 504.

24 Ibid., at 504-514.

25 Ibid., at 504 . 
through an internal process of consensus-building. ${ }^{26}$ And although all states are a product of conflict, consensus and contrivance, it must be remembered that the postcolonial African state is by far the most contrived of all!

\section{3. "Righting", Restructuring and Rejuvenating the Postcolonial African State:}

I have argued in my previous work that certain doctrinal tendencies of international law (such as the facilitation of homogenization ${ }^{27}$ and peer-review ${ }^{28}$ ) have traditionally facilitated the process via which the postcolonial African state has tended to coercively retain its restive sub-state groups, almost always with profoundly negative implications for the legitimacy, stability, peacefulness, and effectiveness of the relevant states. ${ }^{29}$ Given the deep socio-cultural cleavages and serious structural tensions that characterize the postcolonial African state, this conflictual and often violent result is not all that surprising. ${ }^{30}$ However, as I have also shown elsewhere, international law is in many senses slowly beginning to turn slightly in the direction of alternative doctrines and tendencies, such as autonomy ${ }^{31}$ (rather than homogenization) and infra-review ${ }^{32}$ (instead of peer-review). This

26 Ibid.

27 As used here, "homogenization" refers to the tendency in international law to facilitate the largely coercive attempts by states to "form cohesive, culturally unitary nations out of their distinct, diverse component polities." See ibid., at 518.

28 As used here, "peer review" refers to the tendency in international law to facilitate "the process of determining state legitimacy... according to the ipse dixit or "say so" of pre-existing states. This determination is not necessarily made with reference to the nature or qualities of the would-be state, or of any of its constituent sub-state groups." See ibid., at 515.

29 See Okafor (O.C.), "Re-Defining" supra note 1 at 53-77.

30 See Okafor (O.C.), "Martyrdom" supra note 7 at 505 and 521-526.

31 As used here, the term "autonomy" refers to the slight turn in favour of more respect in international law and society for the rights, desires and wishes of the sub-state socio-cultural groups that constitute most states (especially for their minority and self-determination rights). See $i b i d$. at 520-521.

32 As used here, the term "infra-review" refers to the requirement that the decisionmaking process regarding state legitimacy pay significant attention to the "sayso" and rights of the socio-cultural groups that constitute a given state. See ibid., at 515 . 
turn may allow international law and institutions to avoid contributing in nearly as much measure to the generation of tensions and violence within the post-colonial African state. ${ }^{33}$

As these linkages among these specific traditional doctrines and tendencies of international law, the structural illegitimacy of the postcolonial African state, and the generation of conflict within many such states, have already been well explicated in other books and articles, I will not dwell of them here. ${ }^{34}$ Rather, what I propose to do briefly in this section is to show how the international legal regime (and to a much lesser extent, certain domestic regimes within African states) have begun to contribute to the righting, restructuring - and therefore to the eventual rejuvenation - of the post-colonial African state. The promotion and sustenance of these righting and restructuring tendencies is seen as key to countering the negative effects that the homogenization and peer-review tendencies have had on the postcolonial African state, and in also facilitating the incipient - if still shaky - turn toward the relatively more desirable autonomy and infra-review tendencies.

\section{Righting the Postcolonial African State}

The need to "right" the postcolonial African state refers primarily to the international legal imperative of utilizing and adhering to international human rights law norms (especially those relating to self-determination and minority rights) in the processes of state-formation or even state-disintegration in Africa (as elsewhere). The use of the term "righting" also refers to a normative standard; i.e. it suggests that adherence to these minority rights and self-determination norms is in fact the right thing to do from a policy and moral perspective. As obvious as the necessity of adherence to such norms in statecraft may seem to some, international law has until recently tended to favour, rather than counter, attitudes that detracted from the observance of the requirements of these norms. As we have seen, the law has tended to favour the coercive retention of sub-state

33 Ibid., at 517-518 and 520-521.

34 For example, see Okafor (O.C.), "Re-Defining" supra note 1; and Okafor (O.C.), "Martyrdom" supra note 7. 
groups within established and generally homogenizing states, while paying scant attention to the "say so" or infra-review of such groups regarding the legitimacy of their continued membership within these established states. These two attitudes (i.e. homogenization and peer-review) tend to negative rather than adhere to the minority and self-determination rights that are becoming entrenched in international law. Thankfully, as strong and dominant as they remain, these attitudes have begun to wane in significant though still slight measure. $^{35}$

International human rights law, especially articles 1 and 27 of the International Covenant on Civil and Political Rights; article 1 of the International Covenant on Economic, Social and Cultural Rights; articles 19-23 of the African Charter on Human and Peoples' Rights; and the Declaration on the Rights of Persons Belonging to National, Ethnic, Religious and Linguistic Minorities, imposes reasonably clear obligations on states to respect the rights of their constituent sub-state groups, especially those who are minorities within those states. ${ }^{36}$ It is no secret that most African states have at the formal level consented to be bound by most of these obligations. These minority rights include the right of such groups to use their own languages, to participate fully in political and economic life, to self-determination (at least in the form of local autonomy), to maintain their own associations, and to non-discrimination. In particular, the African Charter, to which every African state, with the sole exception of Morocco, has adhered, mandates, inter alia, the equality of all the sub-state groups that constitute each African state, ${ }^{37}$ outlaws the "domination of a people by another," 38 guarantees the right of all peoples to "existence," and "self-determination," 39 guarantees the

${ }^{35}$ See also Orentlicher (D.F.), "Separation Anxiety: International Responses to Ethno-Separatist Claims" (1998) 23 Yale Journal of International Law 1, at 3-4.

36 See the International Covenant on Civil and Political Rights, 1966, 999 UNTS 171; the International Covenant on Economic, Social and Cultural Rights, 1966, 993 UNTS 3; the African Charter on Human and Peoples Rights, 1981, (1982)

21 ILM 58; and the Declaration on the Rights of Persons Belonging to National, Ethnic, Religious and Linguistic Minorities, GA Res. 47/135. 18 December 1992.

37 See article 19.

38 Ibid.

39 See article 20(1). 
right of all peoples to freely control their wealth and natural resources, ${ }^{40}$ and clearly states that "colonized or oppressed peoples shall have the right to free themselves from the bonds of domination." ${ }^{, 41}$ Clearly, these rights, even when they involve selfdetermination, apply even within established states such as postcolonial African states. ${ }^{42}$ The term "all peoples" has been applied to the internal context in at least one official interpretation of the African Charter. And that expression has also been so applied in a fairly recent Canadian decision. This reading of that term was rendered in the Katanga Case as well as in the Quebec Reference Case in Canada. ${ }^{43}$ What is more, a small number of African states have begun to include minority rights and the self-determination norm in their own domestic constitutions, albeit to varying degrees. ${ }^{44}$

The effect of this application of self-determination and minority rights to the internal sphere of states is that under contemporary international law, these states cannot now stand lawfully configured or in future be re-configured in ways that violate these minority rights and self-determination norms. Statecraft ought henceforth to be framed and shaped by the dictates of these norms. Thus, if statehood is to be "righted" in Africa (both in terms of adherence to the relevant

40 See article 21

See article 20(2).

42 See Umozurike (U.O.), The African Charter on Human and Peoples' Rights (The Hague: Martinus Nijhoff, 1997) 53-54.

43 See Reference Re Secession of Québec (1998) 2 S.C.R. 217. See also Okafor (O.C.), "Entitlement, Process, and Legitimacy in the Emergent International Law of Secession" (2002) 9 Inter national Journal on Minority and Group Rights 41.

See section 235 of the South African Constitution which states that: "The right of the South African people as a whole to self-determination, as manifested in this Constitution, does not preclude, within the framework of this right, recognition of the notion of the right of self-determination of any community sharing a common cultural and language heritage, within a territorial entity in the Republic or in any other way, determined by national legislation." See (http://www.strategicassessments.org/library/resources/South_Africa_Consti tution.pdf) (visited 20 May 2006). See also Henrad (K.), Minority Protection in Post-Apartheid South Africa (Westport, Connecticut: Praeger, 2002) at 116. And article 39 of the Constitution of the Federal Democratic Republic of Ethiopia contains self-determination (up to and including secession rights), language, cultural and political representation rights for all its constituent "nations, nationalities and peoples." See (http://www.ethiopar.net/English/cnstiotn/conchp32.htm) (visited 20 May 2006). 
international law imperatives and in the sense of doing the right thing) those who lead the processes of state-formation or statedisaggregation on the African continent must begin to pay far greater attention to the dictates of the international and African selfdetermination and minority rights norms that seek to peaceably order state-building on the continent.

Yet, as is widely recognized, like statecraft elsewhere, African statecraft has generally not been as attentive as it ought to be to this imperative of "righting" the state. For the most past, the postcolonial African state continues to muddle through and endanger its corporate future by coercively retaining its constituent groups, and scarcely attending as adequately as it ought, to the infra-review of its constituent sub-state groups. This is one good reason to focus, as we will in the section that follows, on the necessity for the restructuring of the postcolonial African state along the lines dictated by the same norms that must guide its righting.

\section{Restructuring the Postcolonial African State}

Given that the international legal entitlement of the sub-state groups that constitute the postcolonial African state to some form of autonomy, as well as to infra-review of the acceptability to them of their continued membership within their current states, and given the intensity of the intra-state conflicts over autonomy and the like that has been experienced within almost every postcolonial African state, there appears to be a need to find peaceful ways of restructuring the state in Africa in order to better satisfy the yearnings of its constituent peoples. ${ }^{45}$ As Makau Mutua has previously, and insightfully, warned us, confronted as it has always been by an intense structural legitimacy crisis, the postcolonial African state will be reconfigured one way or the other, either peaceably or violently. ${ }^{46}$ The task is to make that reconfiguration as peaceable as it can be.

45 For another scholar's argument that the righting of statecraft in Africa, via the application of the African Charter to the area, justifies the restructuring of African states based on power-sharing arrangements, see Jinadu (L.A.), supra note 21 at 23.

46 See Mutua (M.), supra note 10 at 536 . 
Much as this imperative has been long recognized by other scholars such as Makau Mutua, African statecraft has yet to come close to an adequate recognition of this imperative. Indeed, the dominant tendency is for African states to reject self-determination claims, ${ }^{47}$ and to view even less consequential minority rights claims with some suspicion. Far-too-many African states are still configured in highly centralized and homogenizing ways that allow far too little autonomy to the socio-cultural groups that constitute them, actually guarantee too few minority rights to their constituent sub-state groups, and provide far-too-little real avenues for meaningful infra-review of the structural legitimacy of the relevant states. Nigerian and Ethiopian quasi-federalism, ${ }^{48}$ and the power-sharing arrangements in Ethiopia (i.e. special representation in parliament for minorities) and in Nigeria (as per the federal character principle) ${ }^{49}$ are some of the mild exceptions to the generally centralizing trend within the postcolonial African state. And even many of the relatively few states that have quite commendably subscribed to federal constitutions and political arrangements have in practice all but neutralized the autonomy allowed by such federal arrangements, and have in reality remained overly centralized. And few, if any, African states brook even the most harmless discussions about infra-review, fearing that it would lead to rampant secession (and - as they see it - much chaos).

This tendency to over-centralize and homogenize the postcolonial African state is, as we have already seen, a major cause of the structural tensions that lead to conflict and violence on the continent. That is the chief reason why the state in Africa needs rejuvenation via its righting and restructuring; not simply to reconstitute it in its prevailing form, but to re-jiggle its structures in ways that have a greater chance of earning it the widespread legitimacy of its constituent peoples.

47 See Ankumah (E.), The African Commission on Human and Peoples' Rights (The Hague: Martinus Nijhoff, 1996) at 163.

48 See Gana (A.T.) and Egwu (S.G.) (eds.), Federalism in Africa: Framing the National Question (Trenton, New Jersey: Africa World Press, 2003) at 35. See also Jinadu (L.A.), supra note 21 at 24-30.

49

See Jinadu (L.A.), ibid. at 24-30. 


\section{Rejuvenating Postcolonial African State}

Implied in much of the foregoing is the fact that the rejuvenation of the currently troubled and weakened postcolonial African state would depend quite heavily on the extent to which it is righted and accordingly restructured. As I have argued elsewhere, put summarily, the argument in favour of rejuvenating the postcolonial African state through its righting and restructuring is that an international legal move from homogenization toward multinational statehood would inhibit leaders in Africa from relying on the rules and norms of international law in their bids to forcibly homogenize their states. ${ }^{50}$ African states would thus be encouraged by the new stance of the law (which pays more heed to self-determination and minority rights) to seek more peaceful means of securing their post-colonial borders and population composition. ${ }^{51}$ Referenda regarding the integrity of African states, their structural organization, and the relationship among their different sub-state groups might then become more common and accepted. ${ }^{52}$ And truly con-federal and federal structures and practices may take far deeper root in more African countries. ${ }^{53}$ This would then lead to a reconfigured postcolonial African state that is better able to avoid the structural tensions and consequent conflicts that have characterized it since its very beginnings.

As this imperative task of righting, restructuring - and therefore rejuvenating - the postcolonial African state is far too important and consequential to be left to the affected states alone, and because of other important reasons that will be discussed in the next section, a suggestion is made in that section for the establishment of a new mechanism that will focus on, facilitate and foster the kind of state-building renaissance on the African continent that is hoped will be generated by attempts to right and restructure the postcolonial African state.

50 See Okafor (O.C.), "Martyrdom" supra note 7at 527.

51 Ibid.

52 Ibid.

53 Ibid. 


\section{Toward an AU Special Commission on National Minorities}

How can the ongoing, if as yet very weak, trend toward the righting, restructuring - and thus the rejuvenation - of the postcolonial African state be facilitated, bolstered and sustained in order to prevent, manage and even resolve many of the conflicts that afflict the postcolonial African state? As we have seen, by writing selfdetermination or minority rights norms into their constitutions and by establishing federal and power-sharing state structures, a few African states have begun - albeit mostly at a formal level - the effort to right, restructure - and thus rejuvenate - the postcolonial African state. For example, South Africa has established a Commission for the Promotion and Protection of the Rights of Cultural, Religious and Linguistic Communities; ${ }^{54}$ and Nigeria now operates a functional Federal Character Commission. Yet, as important, necessary, and commendable as these domestic efforts are, the structural crisis of state legitimacy in Africa that has been generated by the national minority problems that have afflicted the postcolonial African state since its very beginnings is far too serious and far too key and widespread as a source of conflict and violence on the continent to be left entirely to the vagaries of domestic politics. As such, there is a need for a meta-state mechanism to be devoted to the imperative and urgent task of helping to rejuvenate the postcolonial African state via its systematic righting and restructuring. The amelioration of so central a statebuilding challenge as the national minority problem (and attendant state legitimacy crisis) in Africa deserves the concerted efforts of all interested parties on the continent. It certainly deserves the attention of our continental institutions.

Aside from the seriousness of the state legitimacy crisis in Africa, another reason that commends the establishment of such a meta-state mechanism is the need to deploy relatively triadic structures in the attempt to manage or resolve the national minority questions that have led to the structural legitimacy crisis that afflicts the post-colonial African state. By a triadic structure is meant the management or

54 See Section 181 of the Constitution of Republic of South Africa; and the First Periodic Report of South Africa to the African Commission on Human and Peoples' Rights, 2001 (submitted 2005) (on file with the author). 
adjudication of disputes by "a relatively detached and independent third party." management structure is one that is limited to the parties to the dispute themselves or to the parties and an institution that is controlled by one of them. A good, and in fact common, example of such a dyadic structure is a situation in which a dispute between a majority group that extensively controls and dominates the central government of a country and one of the minority groups in that country is referred to an organ of that same central government. In the intensely multi-national African state context, as elsewhere, where majority sub-state groups often exert extensive control over the central government much to the detriment of the minority groups, and where inter-group trust is - to say the least - lacking, triadic structures (i.e. the injection of an external institution or body as the central dispute manager or arbiter) are likely to be significantly more effective than the inevitably dyadic structures of the kinds of domestic mechanisms deployed toward the management of inter-group tensions and conflict within such states. This is because among the weaker sub-state groups within these states, triadic dispute management mechanisms tend to inspire far more confidence than dyadic models regarding the fairness - and therefore the legitimacy - of the process of dispute management, and of its outcomes. And since the very tensions and conflicts that are to be subjected to dispute management tend to originate from a sense of deprivation, unfair treatment, and being dominated, and are unlikely to be doused or ameliorated when the dissatisfied minority or less powerful sub-state group is not fully confident of the fairness and legitimacy of the dispute management process and outcomes, it is only reasonable to conclude that non-triadic dispute settlement models are less likely to be effective in such circumstances. This much is recognized in Tim Murithi's conclusion that: "There is therefore a vital third party role that the African Union [a meta-state institution] can play in all future crisis situations on the continent, by intervening in the tense situations before they escalate." 56

55 See Okafor (O.C.), "Entitlement" supra note 42 at 56.

56 See Murithi (T.), supra note 1. Emphasis supplied. 
Also embedded in Murithi's call for the deployment of more triadic mechanisms toward the management of inter-group tensions and the structural crisis of legitimacy that afflicts the postcolonial African state is an expressed preference for the deployment of an inter-African institution to do this job. Despite the budgetary difficulties that such inter-African bodies often face, this is - in my view - the correct posture to adopt. For, to be optimally effective, the proposed metastate mechanism must still be inter-African and "owned" by Africans. It must not be perceived as a foreign body imposed on Africans by those with whom Africa has not had a happy history of intervention. This is largely because of the well-documented incidence of postcolonial "immune reaction" within virtually every African state to foreign, especially unilateral non-African interventions. ${ }^{57}$ The point here is that far-too-many interventions fail on an African continent that has only recently been decolonized largely because of their perceived excessive foreignness and illegitimacy as somewhat analogous to the colonial plunder and misrule of most African polities by a few European states, many of whom continue to exert a disproportionate level of power within non-African international institutions.

As such, other than because of the budgetary problems that it often faces, being the foremost inter-African institution of our time, the African Union is well suited to host and provide the kind of mechanism that is being suggested here. For one, the Constitutive Act of the African Union recognizes the imperative "need to promote peace, security and stability" important way to promote peace, security and stability within Africa than the effective management of the deep-seated and large scale national minority problem that afflicts the postcolonial African state through the preventive righting, restructuring - and eventual rejuvenation - of that state. Secondly, since the African Charter on

57 See Deng (F.), "State Collapse: The Humanitarian Challenge to the United Nations" in Zartman (I.W.) (ed.), Collapsed States: The Disintegration and Restoration of Legitimate Authority (Boulder: Lynne Rienner, 1995) at 211.

58 See the Preamble of the Constitutive Act of the African Union, supra note 4. On the identity and nature of the AU's institutions, See Udombana (N.J.), "The Institutional Structure of the African Union: A Legal Analysis" (2002) 33 California Western International Law Journal 69. 
Human and Peoples' Rights, the African Commission on Human and Peoples' Rights, and the African Court on Human and Peoples' Rights (the primary norms and processes relating to the vindication and enjoyment of self-determination and minority rights in Africa) are all AU institutions, ${ }^{59}$ the $\mathrm{AU}$ can help right the postcolonial African state by facilitating the application of these norms in the domestic context. Thirdly, as a relatively detached third party which enjoys significantly greater legitimacy in Africa than other such international institutions, the AU can play a key triadic and preventive role in ensuring the fairness, legitimacy - and therefore effectiveness - of negotiated attempts to restructure specific African states according to the dictates of the relevant international norms, especially as mandated in the selfdetermination and minority protection clauses of the African Charter. It is in these ways that the AU can play a key role in the rejuvenation of the postcolonial African state.

However, in order to be able to play this historic role effectively, the AU ought to establish a new, dedicated, semi-autonomous sub-institution that will be devoted to the national minority question that has seriously troubled the postcolonial African state since its very beginnings. Aside from the fact that a crisis that is so central and consequential for Africa as the state legitimacy crisis (that has resulted from the national minority problem) in most African states deserves far more attention than it can get from any institution that multi-tasks and is not focused on this one basket of issues, existing $\mathrm{AU}$ institutions are simply not suitable for the task. Focused as it is on the adjudication of legal disputes, the new African Court on Human and Peoples' Rights is not equipped to serve as a preventive body and is simply not suited to the intensely political task of attempting to douse inter-group tensions within states well before they escalate into conflicts. Although more of a political animal (if still quasi-judicial in nature), the African Commission on Human and Peoples' Rights is clearly more suited to reaction (in deciding cases brought before it) than active direct intervention in tense situations as a way of preventing conflict and violence. And although there is little that

59 For more on this point, see Murray (R.), Human Rights in Africa: From the OAU to the African Union (Cambridge: Cambridge University Press, 2004). 
prevents it from developing its incipient preventive capacity, it is better for it to focus on its more developed adjudicatory function. What is more, the African Commission is already burdened with a multitude of tasks to an extent that obstructs its ability to focus squarely on the national minority question in Africa. This is of course not to discount the ways in which both the African Court and the African Commission can empower minority groups in Africa by providing them with an avenue for highlighting their claims of deprivation and oppression at the hands of majority groups and/or the state. ${ }^{60}$ As importantly, even though they are equipped with some preventive capacity and charged $t$ with the performance of some preventive functions, other AU bodies such as the Assembly of Heads of State and Government, the Executive Council, and the Peace and Security Council are simply far too politicized or much too broadly focused to perform fairly, legitimately, and effectively, the kind of focused, dedicated and specialized function that is needed to tackle squarely the national minority question in Africa. ${ }^{61}$ The AU organ that comes closest to fitting the bill here is the Peace and Security Council. $^{62}$ Upon its physical establishment in 2004, this council replaced the defunct OAU/AU Mechanism for Conflict Prevention, Management and Resolution. ${ }^{63}$ Supported by the AU Commission, a Panel of the Wise and a Continental Early Warning System, the Peace and Security Council is an important avenue for AU preventive and reactive action in the area of peace and security. However, this Council is far too politicized and too broadly focused to serve the purpose of ameliorating the national minorities' problem that is chief source of Africa's state legitimacy crisis. In any case, it is instructive

\footnotetext{
${ }^{60}$ See Murithi (T.), supra note 55 at 105.

${ }^{61}$ For a description and analysis of the nature of these organs, see Udombana (N.J.), "Unfinished Business" supra note 4 at 67-87.

62 See the Protocol Relating to the Establishment of the Peace and Security Council of the African Union, adopted on 9 July 2002, in force since 26 December 2003, on-line: (http://www.africaunion.org/root/au/organs/psc/protocol_peace\%20and\%20security.pdf) (visited 19 June 2006).

63 This mechanism was established in 1993 by the Cairo Declaration, OAU Doc. AHG/Decl.3 (XXIX), 28-30 June 1993). It has been incorporated into the new AU order by the Decision on the Implementation of the Sirte Summit Decision on the African Union, OAU Doc. AHG/Decl.3 (XXXVII), 11 July 2001.
} 
that despite the fact that the Peace and Security Council has been in existence since 2004, Tim Murithi - a keen observer of inter-African politics - felt able to declare in 2005 that African statebuilding practice has so far tended not to be preventive. If prevention rather than reaction is the raison d'être of the proposed new institution, it is clear that the existing conflict prevention mechanism has so far not played, and is unlikely to play, that role effectively. It is for all of these and other such reasons that I am of the view that, at the very least, existing $\mathrm{AU}$ institutions need to be buttressed through the creation of a new, specialized and dedicated institution.

Much in line with my earlier call for an OAU Special Commission to undertake the same kind of tasks, it is proposed here that this new body, this new dedicated, focused, and specialized preventive interAfrican institution, be styled the $A U$ Special Commission on National Minorities. Recognition of the necessity for the creation of this type of avenue for the ventilation and management of sub-state group (especially minority group) grievances within states is not new. For instance, Gudmundur Alfredsson and Danilo Turk had long called on states to allow such groups increased access to both international policy-making and implementation bodies. ${ }^{64}$ Similarly, Diane Orentlicher has also called for "binding arbitration procedures" to perform this kind of function. ${ }^{65}$ More specifically, Tim Murithi has recently urged the appointment of an AU Special Representative on Peacebuilding, to perform somewhat similar, if broader, functions as the proposed special commission. ${ }^{66}$

This proposed commission should be composed of five eminent and influential African leaders (defined to include not just serving or former heads of state), whose identities must reflect the geographical, racial, religious, and gender diversity of the African continent. Such a composition, and the semi-autonomous character of the commission, would likely make it to be more effective than existing AU institutions

${ }^{64}$ See Alfredsson (G.) and Turk (D.), "International Mechanisms for the Monitoring and Protection of Minority Rights: Their Advantages, Disadvantages and Interrelationships" in Bloed (A.), Leicht (L.), Nowak (M.) and Rosas (A.) (eds.), Minority Human Rights in Europe: Comparing International Procedures and Mechanisms (Dordrecht: Martinus Njhoff, 1993) at 181.

66 See Orentlicher (D.), supra note 34 at 74-77.

See Murithi (T.), supra note 1 at 109. 
at tackling the national minority question in Africa. The eminence and moral authority of the five special commissioners would endow the commission with a reasonable degree of influence on the relevant African Governments. The fact that the commission is to be composed of five eminent persons rather than a single commissioner has the advantage of facilitating the greater institutionalization of its dispute prevention/management process rather than its over-personalization. This is an important feature given the struggle in many African states to overcome their own unhappy postcolonial histories of personal rule, and also given the need for the Commission's decisions to be subjected to internal checks and balances. In this way will the proposed Commission differ from the High Commissioner on National Minorities established by the Organization for Security and Cooperation in Europe (OSCE) ${ }^{67}$ Furthermore, the autonomy of the AU Special Commission from African states, and even from the main political Organs of the AU, will also help bolster and cement its triadic character, thus enhancing the perceived legitimacy of its processes and decisions, and enhancing its effectiveness in the long run. The Commission will also have the significant advantages of specialist expertise, resulting from its dedication to a single basket of related issues. Such expertise will be important if the commission is to quickly become effective in tackling this central and devastating problem of the postcolonial African state. Given how urgent and imperative the resolution of the national minorities question is in Africa, and how devastating to the continent its ill- or non-resolution has been thus far, these advantages - no matter how slight they may seem - are important nevertheless.

\section{Conclusion:}

In conclusion, I have argued that given the status of the nationality minority problem that confronts the postcolonial African state as the key cause of the state legitimacy crisis that confronts that state, and given the fact that this structural legitimacy crisis that has afflicted

67 See Brenninkmeijer (O.), The OSCE High Commissioner on National Minorities: Negotiating the 1992 Conflict Prevention Mandate (Geneva: PSIO, 2005). 
almost all African states from their very beginnings is by far the principal cause of high tensions, conflicts and violence on the continent, it is Africa's key state-building challenge. As such, it deserves far more focused and systematic attention from inter-African institutions than it has so far received. I have also argued that in order to rejuvenate the postcolonial African state, it must in effect be saved from itself. It must be "righted" and restructured in accordance with the increasing if still slight tendency in international law to pay attention to minority rights and self-determination norms in the conceptual ordering of state-formation and disaggregation. It was thereafter suggested that if this process of righting and restructuring - and therefore rejuvenating - the postcolonial African state is to be facilitated, bolstered and sustained, the African Union (AU) needs to - as a matter of urgency - appoint a Special Commission on National Minorities to guide and order this process. That this process must be allowed to happen and must be systematic and preventive (rather than chaotic and reactive) is underlined by Makau Mutua's accurate warning, with which I am in complete agreement that over time the postcolonial African state will definitely be reconfigured, and that the task is to as much as possible avoid further violent reconfigurations of that state by preemptively finding ways to allow its peaceable reconfiguration. It is hoped therefore that this discussion has contributed, however modestly, to the search for peaceable ways of reconfiguring and therefore ennobling the postcolonial African state. 